Manuscript for submission to Journal of Biomedical Materials Research Part A

\title{
Biomaterials functionalized with nanoclusters of integrin- and syndecan-binding ligands improve cell adhesion and mechanosensing under shear flow conditions
}

Fatemeh Karimi ${ }^{1,2,3}$, Varsha Jagannath Thombare ${ }^{4}$, Craig A Hutton ${ }^{4}$, Andrea J O’Connor ${ }^{1}$, Greg G Qiao $^{2} *$, Daniel E Heath ${ }^{1 *}$

1 Department of Biomedical Engineering, Particulate Fluids Processing Centre, University of Melbourne, Parkville VIC 3010, Australia

${ }^{2}$ Polymer Science Group, Department of Chemical Engineering, Particulate Fluid Processing Centre, University of Melbourne, Parkville VIC 3010, Australia

${ }^{3}$ Graduate School of Biomedical Engineering, University of New South Wales, Sydney, Australia

${ }^{4}$ School of Chemistry and Bio21 Molecular Science and Biotechnology Institute, University of Melbourne, VIC 3010, Australia

\section{Co-corresponding Authors}

Dr Daniel E Heath

Email: daniel.heath@unimelb.edu.au

Tel: +61 383442579

Professor Greg Qiao

This is the author manuscript accepted for publication and has undergone full peer review but has not been through the copyediting, typesetting, pagination and proofreading process, which may lead to differences between this version and the Version of Record. Please cite this article as doi: $10.1002 / \mathrm{jbm} . a .37024$

This article is protected by copyright. All rights reserved. 
This article is protected by copyright. All rights reserved. 


\begin{abstract}
We have engineered biomaterials that display nanoclusters of ligands that bind both integrin and syndecan- 4 cell receptors. These surfaces regulate cell behaviours under static conditions including adhesion, spreading, actin stress fibre formation, and migration. The syndecan-4 receptors are also critical mediators of cellular mechanotransduction. In this contribution we assess whether this novel class of materials can regulate the response of cells to applied mechanical stimulation, using the shear stress imparted by laminar fluid flow as a model stimulus. Specifically, we assess endothelial cell detachment due to flow, cell alignment due to flow, and cell adhesion from the flowing fluid. A high degree of cell retention was observed on surfaces containing integrin-binding ligands or a mixed population of integrin- and syndecan-binding ligands. However, the presence of both ligand types was necessary for the cells to align in the direction of flow. These results imply that integrin engagement is necessary for adhesion strength, but engagement of both receptor types aids in appropriate mechanotransduction. Additionally, it was found that surfaces functionalised with both ligand types were able to scavenge a larger number of cells from flow, and to do so at a faster rate, compared to surfaces functionalized with only integrin- or syndecan-binding ligands. These results show that interfaces functionalized with both integrin- and syndecan-binding ligands regulate a significant range of biophysical cell behaviours in response to shear stress.
\end{abstract}

Keywords: Multivalent, endothelial cell, co-receptor, mechanotransduction, cell scavenging 


\section{Introduction}

Advances in biomaterials science are critical to the development of new biomedical devices and improvements in tissue engineering and organ-on-a-chip technologies. Strategies for developing these next generation materials can often be informed through understanding how cells interact with their native environment, the extracellular matrix (ECM). Integrin receptors are the main cell adhesion molecules that regulate a cell's interactions with the ECM. This detailed mechanistic knowledge has resulted in the development of bioactive materials that are functionalised with polypeptide motifs - or ligands - that regulate cell adhesion through specific interactions with a cell's integrin receptors [1-3]. For nearly thirty years, researchers have functionalised synthetic materials with a variety of integrinbinding ligands such as the RGD, GFOGER, REDV, and CRRETAWAC polypeptides to promote specific, integrin-mediated cellular adhesion [4-13].

While integrins are considered to be the primary ECM receptors, they are not the only receptor type responsible for ECM adhesion. Specifically, biological research has illustrated that the syndecan-4 receptor is a critical co-receptor that must be engaged with integrins for optimal cell adhesion, mechanosensing, and initiation of intracellular signalling [14-20][21-24]. For instance, fibroblasts require engagement of both syndecan- 4 and $\alpha_{5} \beta_{1}$ integrins for focal adhesion formation and stress fibre development, whereas neither is sufficient alone [25]. To the best of our knowledge, we are the first to develop synthetic biomaterials that leverage the synergy between integrin and syndecan-4 receptors through the functionalisation of materials with ligands that bind both receptors types [26]. 
Previously, we have developed a low-fouling biomaterial platform that enables the presentation of nanoclusters of cell adhesive ligands. This nano-scale presentation of multivalent ligands facilitates receptor clustering within the cell membrane and promotes focal adhesion formation [3]. We then illustrated that the nanoscale clustering of the integrin-binding RGD ligand can be used to increase adhesion, endothelialisation rate, and migration speed of endothelial cells under static conditions compared to surfaces that displayed a similar overall density of ligands with a random distribution [27]. Next, we illustrated that surfaces that display nanoclusters of mixed populations of integrin and syndecan-4 ligands synergistically increase endothelial cell adhesion and increase the rate of surface endothelialisation under static conditions compared to those that displayed only clusters of integrinbinding ligands [26].

In this contribution, we are most interested in the documented role of syndecan-4 receptors in cellular mechanotransduction [28-30]. Endothelialisation of cardiovascular biomaterials is an important example of a process that depends on the biomaterial surface design to achieve the desired cell behaviour under applied mechanical forces. As such, we used endothelial cells as the model cell type in this study and used a laminar shear flow chamber to mechanically stimulate the cells with shear stresses over a physiologically relevant range. Specifically, we assessed how this new generation of biomaterials impacts three key endothelial cell behaviours under flow: detachment from the material surface due to flow, cellular reorganization and alignment under flow, and attachment to the surface from flow. These behaviours were chosen because they provide biophysical insight into the complementary role of integrins and syndecans in cell binding and are critical for improving the endothelialization of biomedical devices: 1) Cell adhesion from flow was assessed as many recent studies focus on in situ endothelialization through the capture of circulating endothelial progenitor cells (EPCs) from the blood stream [31-33]. Thus generating surfaces with improved scavenging capacity is 
desired. 2) Cell detachment from a surface is also of concern. Cells that are seeded onto the interface or that are scavenged from the flow must be firmly attached to prevent exfoliation to maintain the integrity of the endothelium [31,32]. As such, engineering surfaces to promote firm EC adhesion is required. 3) Cellular mechanotransduction is also critical. ECs align and elongate in the direction of flow in vivo, and this mechanotransduction is an important regulator for many key cellular functions including apoptosis, morphological remodelling, cell cycle progression, and production of NO, which altogether contribute to atheroprotective effects of the endothelium [34-37]. As such, development of surfaces that promote appropriate EC mechanosensing is necessary.

Herein, we illustrate that integrin engagement is critical to generate strong attachment between cells and the interface. However, engagement of both integrin and syndecan receptor types is necessary to achieve the appropriate mechanotransduction of cells under flow and to improve the scavenging of cells from flow. Additionally, syndecan-4 is ubiquitously expressed by the adherent cells of the body; therefore, we expect this new class of biomaterials could be used to improve the interactions between biomaterials and a variety of other cell types [38,39]. 


\section{Materials and Methods}

\subsection{Polymer synthesis and surface preparation}

The polymers were synthesized and the surfaces were prepared as previously described [26]. Briefly, a copolymer of methyl methacrylate/PEG-methacrylate (MP) and a terpolymer of methyl methacrylate/PEG-methacrylate/PEG-methacrylate-norbornene (MPP) were synthesized via reversible addition-fragmentation chain transfer (RAFT) polymerization. The MPP polymer was functionalized with the cysteine-terminated syndecan-4-binding AG73 peptide or the integrin-binding RGD peptide through thiol-ene coupling to generate MPP-AG73 or MPP-RGD polymers, respectively. For the peptide functionalisation, the MPP polymer (50 mg), peptide (RGD/AG73, $5 \mathrm{~mol} \%$ of polymer), UV initiator (2,2-dimethoxy-2-phenylacetophenone, 2 wt\% of peptide), and tri(2-carboxyethyl)phosphine (2 mol\% of polymer) were dissolved in dimethyl formamide (DMF), degassed by nitrogen, and irradiated by UV for $10 \mathrm{~h}$. The polymers were then dialyzed (MWCO $2000 \mathrm{Da}$ ) against deionized water for $24 \mathrm{~h}$, lyophilized, and stored at $4{ }^{\circ} \mathrm{C}$. Test surfaces were generated by blending appropriate ratios of the non-functionalized MP polymers with the MPP-AG73, MPP-RGD, or both MPP-AG73 and MPP-RGD polymers. To create polymer test surfaces, $25 \mu \mathrm{L}$ of $10 \mathrm{wt} \%$ polymer solution in DMF:tetrahydrofuran (THF) (3:7) was cast onto cover glass (Knittel Glass, No.1, 24×60 mm) and allowed to dry at room temperature for $48 \mathrm{~h}$ to create surfaces that will be referred to from hereafter as the AG73, RGD, and AG73:RGD(50:50) surfaces, depending on their ligand content.

\subsection{Device Fabrication}

A Hele-Shaw flow chamber was used in this study. The wall shear stress within the device decreases linearly with device length along the longitudinal axis as shown in Figure 1 [40,41]. This device was 
designed by Usami et al. based on the theory of Hele-Shaw flow between parallel plates [40]. The shear stress at the surface is defined by Equation 1 where $\tau_{w}$ is the wall shear stress, $\mu$ is the viscosity of solution, $Q$ is the volumetric flow rate, $h$ is the chamber height $(59 \mu \mathrm{m}), w_{1}$ is the inlet width $(3 \mathrm{~mm}), L$ is the chamber length (50 $\mathrm{mm}$ ), and $z$ is the axial position.

$$
\tau_{w}=\frac{6 \mu Q}{h^{2} w_{1}}\left(1-\frac{z}{L}\right)
$$

A double molding process was used to fabricate the microfluidic device. The fabrication method is presented schematically in Figure 2. A 3D structure of the device was drawn using SolidWorks 3D Design software and a polyacetal mold was fabricated with a CNC milling machine (Fadal, USA). A polydimethylsiloxane (PDMS) intermediate mold was made by mixing a 10:1 (w/w) ratio of silicone macromer solution and curing agent (Sylgard ${ }^{\circledR} 184$ silicone elastomer kit, Dow Corning Corp.), poured over polyacetal mold, degassed in a vacuum oven for $1 \mathrm{~h}$ at room temperature, and cured at $65{ }^{\circ} \mathrm{C}$ for $3.5 \mathrm{~h}$. The cured PDMS was delaminated to produce an intermediate mold. The intermediate mold was then placed in the oxygen plasma apparatus (Plasma cleaner PDC-32G) at high energy for 1 min to generate hydroxyl groups on the surface [42,43]. The treated mold was silanized with trichloro $(1 \mathrm{H}, 1 \mathrm{H}, 2 \mathrm{H}, 2 \mathrm{H}$-perfluorooctyl)silane (Sigma) by placing the mold and $20 \mu \mathrm{L}$ of the silane under a vacuum for $3 \mathrm{~h}$. A fresh PDMS mixture (10:1 w/w macromer solution/curing agent) was then poured into the silanized intermediate mold and degassed under vacuum for $1 \mathrm{~h}$ at room temperature. An oxygen plasma treated glass slide machined with two holes that would become the inlet and outlet ports (1.5 mm diameter) was placed on top of the PDMS and the construct was cured at $65{ }^{\circ} \mathrm{C}$ for 3.5 h. The PDMS and the attached glass slide were delaminated from the intermediate mold and the inlet 
and outlet holes were made in the PDMS using a needle. A polymer coated glass coverslip was treated with oxygen plasma for $30 \mathrm{~s}$ and immediately placed in contact with the PDMS construct to complete the construction of the microfluidic device. A piece of PDMS with the same shape as the channel was placed over the polymer during the plasma treatment step to maintain the chemical integrity of the polymer. Silicone tubing (1.5 mm outer diameter) was inserted into the holes, and bonded to the glass slide by epoxy glue (Duramax). The whole flow chamber device was left for 2 days to ensure good bonding. The flow chambers were incubated overnight in PBS at $37^{\circ} \mathrm{C}$ before experimentation.

\subsection{Cell Culture and maintenance}

Pooled donor Human Umbilical Vein Endothelial Cells (HUVECs) were purchased from Lonza (Australia) and maintained in Clonetics ${ }^{\mathrm{TM}} \mathrm{EGM}^{\mathrm{TM}}$-2 medium containing Endothelial Basal Medium-2 $\left(\mathrm{EBM}^{\mathrm{TM}}-2\right.$ Medium) supplemented with the BulletKit ${ }^{\mathrm{TM}}$, as recommended by the supplier. Cells were cultured at $37{ }^{\circ} \mathrm{C}$ in a humidified $5 \% \mathrm{CO}_{2}$ atmosphere. The culture medium was changed every other day. The cultures were passaged at $80 \%$ confluence and lifted using $0.25 \%$ trypsin-EDTA. For all tests, cells between passages 3 and 5 were used.

\subsection{Flow experiments}

\subsubsection{Cell detachment under flow}

$200 \mu \mathrm{L}$ of cell suspension containing $4.3 \times 10^{5}$ cells in EGM-2 medium was injected into the flow chamber at a flow rate of $100 \mu \mathrm{L} / \mathrm{min}$ using a programmable Aladdin syringe pump and incubated at $37^{\circ} \mathrm{C}$ under no flow condition to allow the cells to adhere. After $7 \mathrm{~h}$ of incubation at $37^{\circ} \mathrm{C}$, a PBS solution containing $0.5 \mu \mathrm{g} / \mathrm{mL}$ of Acridin Orange (AO, Sigma)/Propidium Iodide (PI, Sigma) (1:1 
volume ratio) live/dead stain was flowed through the flow chamber with flow rate of $50 \mu \mathrm{L} / \mathrm{min}$ for 8 min to allow cells uptake the fluorescent stain. After the staining step, the flow rate through the flow chamber was increased in a step-wise manner from 0 to $1.4 \mathrm{~mL} / \mathrm{min}$ over 16 minutes. The magnitude of each step increase was $0.2 \mathrm{~mL} / \mathrm{min}$. Images were taken every 2 minutes by a confocal laser scanning microscope (Nikon A1R) at 20× magnification with automated stage to assess cell detachment from the surfaces under flow. Seven locations were imaged from the inlet to the outlet along the longitudinal axis and at each location three images were taken. Each experiment was performed at room temperature and at least three times on each surface. The images were analysed using ImageJ software (NIH). The viscosity of PBS was measured using a Twin Drive Rheometer MCR 702 (Anton Paar) and was found to be $1.057 \mathrm{mPa}$.s at room temperature. The viscosity was found to be constant over the range of shear rates used in this study. The percentages of cells remaining on the surfaces at various shear stresses were calculated by Equation 2.

Percentage of cells remaining $=\frac{\text { Number of remaining cells }}{\text { Initial number of cells }} \times 100$

Equation (2)

\subsubsection{Cell morphology under flow}

$100 \mu \mathrm{L}$ of serum-free EBM-2 medium containing $1.7 \times 10^{6}$ cells was injected into the flow chambers using syringe pump at a flow rate of $100 \mu \mathrm{L} / \mathrm{min}$ and incubated for $4 \mathrm{~h}$ under no flow condition at 37 ${ }^{\circ} \mathrm{C}$ to allow cells to adhere. Then serum containing EGM-2 medium was introduced to the flow chamber at the flow rate of $10 \mu \mathrm{L} / \mathrm{min}$ for 3 days, $50 \mu \mathrm{L} / \mathrm{min}$ for $10 \mathrm{~h}$, and finally $70 \mu \mathrm{L} / \mathrm{min}$ for $10 \mathrm{~h}$ in an incubator at $37^{\circ} \mathrm{C}$. The cells were then fixed with $4 \%$ paraformaldehyde and permeabilized with $0.1 \%$ Triton X-100 in PBS. The cells were stained with TRITC-phalloidin (1:500) and 4',6-diamino-2- 
phenylindole (DAPI, 1:1000) each for $1 \mathrm{~h}$. The cells were finally washed and covered with PBS and imaged on a confocal laser scanning microscope (Nikon A1R) at 60× magnification. Images were generated by optical sectioning in the z-direction and were analysed using ImageJ software (NIH). The viscosity of EGM-2 medium as measured by rheology was $0.838 \mathrm{mPa} . \mathrm{s}$ at $37{ }^{\circ} \mathrm{C}$ and was found to be constant over the range of shear stresses used in these experiments. The projected cell area, degree of cell alignment to the flow direction, and the width and length of actin filaments on various surfaces was measured using ImageJ software (NIH). The degree of cell alignment to the flow direction was determined by using angle tool to measure the angle formed between the flow direction and the actin filament. At least twenty randomly selected cells on each surface were used for these quantifications.

\subsubsection{Cell capture under flow}

HUVECs in a cell suspension of $1.2 \times 10^{6}$ cells/mL in EGM-2 medium were fluorescently stained with AO/PI (1:1 volume ratio, $0.5 \mu \mathrm{g} / \mathrm{mL}$ each). The stained cells were then flowed through the flow chamber using a syringe pump at a flow rate of $20 \mu \mathrm{L} / \mathrm{min}$ for a period of $20 \mathrm{~min}$. Cell attachment from flow was observed using a confocal laser scanning microscope (Nikon A1R) at 20× magnification. The microscope was programmed to image the biomaterial interfaces every 2 minutes at locations in the devices corresponding to seven distinct shear stresses. At each location, three cell counts were taken, averaged, and presented as cell density. Cell counts were taken between 1 and $4 \mathrm{~cm}$ from the device inlet, along the device axis. The images were analysed using ImageJ software (NIH). The cells were counted manually. Each experiment was performed at room temperature and at least three times on each type of surface and new samples were used in each experiment. The viscosity of EGM-2 medium was measured and was determined to be $1.1 \mathrm{mPa}$.s at room temperature and stable over the range of shear rates assessed in this experiment. 
The attachment rate constants for endothelial cell adhesion on polymer surfaces at various shear stresses were calculated by assuming first-order attachment kinetics using Equation 3 [44]. The rate of change in surface cell density with time $\left(d C_{s} / d t\right)$ is expressed as a function of effective attachment $\left(k_{+}\right)$and detachment $\left(k_{\text {- }}\right)$ rate constants as well as the bulk $\left(C_{0}\right)$ and surface $\left(C_{s}\right)$ cell concentrations.

$$
\frac{d C_{s}}{d t}=k_{+} C_{0}-k_{-} C_{s}
$$

As no cell detachment was observed during these experiments, the detachment rate constant was set to zero. Equation 3 can then be solved for $C_{s}$ (Equation 4).

$$
C_{s}=k_{+} C_{0} t
$$

An effective attachment rate constant $\left(k_{+}\right)$was calculated as the slope of the number of cells adhered per area versus time divided by the bulk cell concentration over the initial linear segment of the curve.

\subsection{Statistical analysis}

Data is reported as mean \pm standard deviation. For tests where multiple means were compared, statistical significance of the data was assessed using one-way analysis of variation (ANOVA) plus a TukeyKramer post-test. For endothelial cells' response to shear flow, a significance value of $\alpha<0.01$ was used. For cell adhesion and detachment under flow, a Student $t$ test was used where ${ }^{* *}$ represents $P<$ 0.01 and * represents $P<0.05$. 


\section{Results}

\subsection{Polymer design, synthesis, and test surface fabrication}

The two low fouling polymers, the MP and MPP polymers, were synthesized by RAFT polymerization to contain $~ 85$ mol\% MMA and $\sim 15$ mol\% of PEG-containing repeat units (Figure 3A) as our previous work has illustrated that this degree of modification with PEG side chains is sufficient to generate a water-stable and low fouling surface upon which bioactive ligands can be immobilized $[26,27]$. The MP and MPP polymers were synthesized to have high molecular weight (128 and $105 \mathrm{kDa}$, repectively) and low PDI (1.17 and 1.12, respectively). The norbornene motifs of the MPP polymer were reacted with the thiol groups of cysteine-terminated peptide ligands through the thiol-ene click chemistry reaction to produce either the integrin-binding MPP-RGD or the syndecan-4-binding MPP-AG73 polymer. The peptide bulk density determined by trace elemental microanalysis and the number of peptides per polymer chains was then calculated. Each of the ligand-functionalized polymers has approximately 5 ligands per chains [26].

The non-functionalized MP polymer was blended with highly peptide-functionalized MPP polymers to generate surfaces that display nanoclusters of integrin- and syndecan-binding ligands (Figure 3B). RAFT polymerization was used as it is a facile, industrially applicable, controlled living radical polymerization capable of synthesizing polymers with high molecular weight and low PDI. Synthesizing polymers with high molecular weight enabled us to regulate the size of the random coils and thus the average spacing of the cell-adhesive ligands with a nano-island. Additionally, the low PDI enabled us to have a good control over the number of ligands per nanocluster. We functionalized polymers with approximately 5 ligands per polymer chain, as previous studies have shown that surfaces that present pentamers of integrin-binding ligands enhance the formation of focal adhesions in adherent 
cells by promoting receptor redistribution and clustering [3]. In our previous work, we varied the concentration of peptide in the material and found that a bulk concentration of $0.01 \mu \mathrm{mol} / \mathrm{mg}$ polymer resulted in an excellent biomaterial surface for cell adhesion and growth [26]. As such, the bulk ligand density in this work was held constant at $0.01 \mu \mathrm{mol} / \mathrm{mg}$ polymer. An RGD peptide (CGGGRGDS) was selected as the integrin-binding ligand. This peptide binds to a variety of integrins including $\alpha_{3} \beta_{1}, \alpha_{5} \beta_{1}$, $\alpha_{v} \beta_{1}, \alpha_{v} \beta_{3}, \alpha_{v} \beta_{5}, \alpha_{v} \beta_{6}$, and $\alpha_{I I b} \beta_{3}$ [2,45-48]. The AG73 peptide (CGGGRKRLQVQLSIRT-amide) was selected as the syndecan-binding ligand. This peptide binds to the syndecan- 1 and syndecan- 4 receptors [49-52]. In our previous contribution, we illustrated that the base polymer was non-adherent to endothelial cells. Additionally, we illustrated that minimal cell adhesion was possible on materials functionalised with the non-sense RGE peptide and a scrambled syndecan-4 peptide. These results indicate that cell adhesion to these materials is due to specific interactions between the ligands present at the material interface and cell adhesion molecules on the cell surface. In this study, we assess the interaction of endothelial cells with these materials under fluid flow conditions. In each sub-section below, the data is presented a range of shear stresses where interesting cellular behaviours were observed.

\subsection{Endothelial Cell Retention under Flow}

Herein, we build on our previous study by investigating how endothelial cells interact with these materials under flow conditions through use of a Hele-Shaw laminar flow chamber, as shown in Figures 1 and 2. This flow chamber design was selected as it enables cellular interactions with the substrate to be assessed over a range of shear stresses in a single experiment $[40,41,53]$. 
The HUVECs were cultured on various polymer surfaces, and a range of shear stresses from 0 to 90 dynes $/ \mathrm{cm}^{2}$ was applied to assess shear-mediated cell detachment as this spans a range of shear stresses present in different arteries and venules in the body [54-56]. A sub-confluent plating cell density was used in this study as we were interested in assessing the interaction between individual cells and the material surface without the influence of neighbouring cells. The percentage of retained cells as a function of shear stress on different surfaces was quantified (Figure 4). In the lower shear stress regime (0 to 14 dynes $/ \mathrm{cm}^{2}$ ) all surfaces had a high degree of cell retention of greater than $95 \%$. However, the cell behaviour began to diverge in the higher shear stresses regime. The largest amount of cell detachment was observed on the AG73 surfaces where only $65 \%$ of cells remained on the surface after being exposed to 90 dynes $/ \mathrm{cm}^{2}$ of shear stress. Both the RGD and AG73:RGD(50:50) surfaces showed robust cellular adhesion of approximately $90 \%$, even at the highest shear stress. At the highest shear stresses tested, 78 and 90 dynes $/ \mathrm{cm}^{2}$, the cell retention is statistically higher on both RGD and AG73:RGD(50:50) surfaces compared to AG73 surfaces.

\subsection{Endothelial cell response to shear flow}

While integrin binding is necessary for adhesion strength, we found that the presence of both integrin and syndecan-binding ligands improves the mechanotransduction of ECs to flow. Representative images of cultured cells on various surfaces after exposure to shear stress (1-3 dynes/ $\left.\mathrm{cm}^{2}\right)$ for $10 \mathrm{~h}$ are shown in Figure 5. ECs are present as confluent monolayers in vivo. Therefore, these experiments were performed at near confluent conditions. Cell spreading, alignment in the flow direction, and formation of actin filaments were increased on surfaces with both integrin- and syndecan-binding ligands compared to surfaces with only integrin- or syndecan-binding peptides. We quantified the projected cell area, degree of cell alignment, number of actin filaments per cell, and length and width of actin filaments 
on the various surfaces (Figure 6A-E). The cell spreading was significantly higher on the surfaces with mixed peptides at all shear stresses (Figure 6A). Additionally, a significantly higher degree of alignment of cells to the flow direction was observed on the surfaces with both integrin- and syndecanbinding peptides (Figure 6B). Additionally, the cells cultured on the surfaces with both peptides exhibited the most well-developed actin cytoskeletons as seen through their statistically greater number of actin filaments and the larger length and width of filaments (Figure 6C-E).

\subsection{Cell capture under flow}

HUVEC adhesion to the functionalized polymer surfaces was performed at various shear stresses as shown in Figure 7. We initially assessed cell scavenging from shear stresses found in the coronary artery (37 dynes $/ \mathrm{cm}^{2}$ ). However, no adhesion was observed over the time frame of this experiment. As such, we continued to reduce the shear stress until cell attachment was observed. An increase in cell adhesion on all polymer surfaces was observed over time. Furthermore, it qualitatively appears that the AG73:RGD(50:50) surfaces exhibited the highest degree of cell adhesion over this range of shear stresses.

Figure 8A-C quantifies the number of attached cells over time and illustrates that the surface density of adherent cells changes as a function of time, shear stress, and surface composition. Cell adhesion increases as the shear stress decreases on all polymer surfaces. Specifically, the cell capture is very low at higher shear stresses but increases at lower shear stresses. Additionally, under conditions where cell 
adhesion does occur, the number of adhered cells increases linearly at short times before beginning to plateau and eventually reaching a saturation point.

Among the different surfaces, the RGD surface has the lowest capacity to scavenge cells from flow followed by the AG73 surfaces. The best cell scavenging capacity is observed on the AG73:RGD(50:50) surface where both the syndecan- and integrin-binding ligands are present. Specifically, after 18 minutes, the number of adhered cells on AG73:RGD(50:50) was statistically higher than on RGD or AG73 surfaces at multiple shear stresses (Figure 8D).

The rate of cell attachment is quantified as by the attachment rate constant, $k_{+}$, where a larger value of $k_{+}$indicates a higher rate of cell adhesion (Figure 8E). The linear section of the curves at short times was used to approximate $k_{+}$when almost all of the sample surface area was available and thus cell crowding effects could be neglected. On all surfaces, the values of $k_{+}$is highest at low shear stresses and decrease to approximately zero when higher shear stresses are applied. Amongst the three surfaces, the largest value of $k_{+}$was observed on AG73:RGD(50:50) surface, indicating the fastest rate of cell scavenging. These results are consistent with our previous observations of EC adhesion under static conditions where surfaces presenting both integrin- and syndecan- binding ligands synergistically increase the EC adhesion rate compared to surfaces functionalized with only one of the ligands [26]. Interestingly, a crossover in the attachment rate constant curves was observed for the RGD and AG73 surfaces at moderate shear stresses $\left(\sim 0.5 \mathrm{dyne} / \mathrm{cm}^{2}\right)$. This indicates that the syndecan-binding ligand is good for cell scavenging at lower shear stresses but loses the cell capture potency at higher shear stresses. 


\section{Discussion}

In this study, we evaluated the impact of a novel biomaterial platform on the biophysics of endothelial cell adhesion, detachment, and mechnosensing as a function of applied shear stress. The material is distinct in that it is functionalised with nanoclusters of a mixed population of cell-adhesive peptides. One ligand type (the RGD tripeptide unit) binds to various integrin receptors, while the second ligand type (the AG73 peptide unit) binds to syndecan-1 and syndecan-4 co-receptors. The syndecan receptors are critical mediators of cellular mechanotransduction.

First, we assessed the ability of cells to remain adhered to the surfaces under shear flow conditions, over a range of physiological shear stresses $\left(0-90\right.$ dynes $\left./ \mathrm{cm}^{2}\right)$ (Figures 4$)$. The wall shear stress in the coronary artery is approximately 37 dynes/ $\mathrm{cm}^{2}$ [54-56]. As such, robust adhesion of endothelial cells at this shear stress is critical to the development of small diameter vascular grafts that can retain an endothelium. These data illustrate that both the RGD and the AG73:RGD(50:50) surfaces are able to retain $\sim 100 \%$ of the endothelial cells at that applied stress. However, the AG73 surface had already begun to experience cell detachment at this level of shear. From these data, it appears that integrin binding is necessary to robustly maintain endothelial cell adhesion over a physiologically relevant range of shear stresses.

Beyond cell adhesion, the endothelial cells must also appropriately respond to the shear and align in the direction of flow, as it is critical towards their function [34,57]. Figures 5 and $\mathbf{6}$ show that the characteristics of the substrate greatly impact ECs' ability to sense and respond to applied mechanical stimulation. Specifically, only cells on the AG75:RGD(50:50) surface showed the ability to align in 
the direction of flow. Additionally, these cells were more spread and had more well-developed actin cytoskeletons. These findings are significant as a study by Baeyens et. al. has shown that syndecan-4 is critical for EC alignment in flow and atheroprotective signalling [24]. Their studies showed that knockdown of syndecan-4 in ECs leads to poor organization of actin stress fibers and misalignment of cells under flow condition both in vitro and in vivo. These changes lead to increased atherosclerosis in sydndecan-4 knock-downed mice. These results illustrate that the canonical method of functionalizing materials with integrin-binding ligands is not sufficient. As such, this new class of materials that engages both integrin and syndecan receptors is superior at enabling cellular mechanotransduction and response to the applied shear stresses.

Finally, we assessed the ability of these surfaces to scavenge cells from flow. The AG73:RGD(50:50) surface was able to adhere the largest number of cells and to do so at the fastest rate. Further, the AG73 surface was able to adhere a large number of cells at low shear stresses, but that ability rapidly deteriorated at higher shear stresses. At all conditions, the RGD surfaces exhibited relatively low levels of cell adhesion. This behaviour could be explained through the interplay of two factors: 1 ) the speed at which interactions form between the receptor and ligand and 2) the strength of the interactions [5860]. From the cell detachment data above, we found that the syndecan-mediated interactions are substantially weaker than the integrin-mediated interactions (Figure 4). The interactions between the positively charged AG73 ligand and negatively charged heparin sulfate chains of the syndecan receptor are largely electrostatic in nature [49-52,59,61]. We hypothesize that these interactions form quickly but are relatively weak. In contrast, the more lock-and-key interactions of the integrin receptors with the RGD peptide are stronger yet slower to form $[59,62,63]$. Therefore, at low shear stresses the fastforming interactions with the AG73 ligand are strong enough to arrest the cells. However, as the shear 
stress is increased, these interactions are too weak to halt cell motion. Therefore, the stronger integrin interactions become necessary at these higher shear stresses [60].

The surfaces that display both integrin and syndecan binding ligands exhibit the best cell scavenging capacity of the surfaces assessed in this study. We hypothesize that on these surfaces the syndecan interactions are acting as a braking mechanism that slows the cells, providing time for the slower but strong integrin interactions to form and halt cell motion. We liken this phenomenon to what is observed when white blood cells, such as leukocytes, are scavenged from circulation to sites of inflammation [64-66]. This scavenging is characterized by stages of rolling adhesion where weak selectin-mediated adhesions slow the cells, followed by tight adhesions that are mediated by integrins. In the case of leukocytes, rolling adhesion is mediated by the interactions between selectins and charged carbohydrates that are fast-forming yet relatively weak. However, this rolling phenomenon reduces a cell's velocity, thus enabling the stronger integrin-mediated interactions to form and stop the cell motion [64-67]. Interestingly, minimal cell adhesion was observed at shear stresses comparable to that present in the coronary artery (37 dynes $/ \mathrm{cm}^{2}$ [54-56]). Many recent articles have proposed to improve the endothelialisation of coronary artery vascular grafts by creating affinity surfaces that scavenge endothelial progenitor cells from flow [68]. These data demonstrate that mechanisms based on the binding of integrins alone will likely not be sufficient, illustrating the need to produce technologies that enable cell adhesion at higher shear stresses.

The polymer blending strategy used in this contribution to generate the peptide-functionalised surfaces provides a rapid and facile way of assessing the impact of global and local ligand density on the cell response. However, the ligand-functionalised polymer chains are randomly distributed across 
the polymer interface. The development of material interfaces with more exact control over ligand positioning is required to unravel specific mechanisms of action that underly this system's advantageous properties and to determine the critical length scales that govern the biophysics of these interactions. However, this contribution illustrates that the co-engagement of integrin- and syndecanbinding ligands is a novel mechanism biomaterials-based mechanism for regulating cell adhesion and mechanotransduction. The syndecan-4 receptor is ubiquitous amongst the adherent cell types. As such, the authors feel that this study can be used to improve the design of many ligand-functionalised biomaterial systems. 


\section{Conclusions}

The data reported herein illustrate that biomaterials functionalised with both integrin- and syndecan-4binding ligands regulate a wide range of EC behaviours including adhesion and mechanotransduction. Specifically, engagement of both ligand types is critical for cell mechanosensing and alignment as well as cell scavenging from flow. These data illustrate that this novel class of materials can be used to improve cell/material interactions and cellular mechanotransduction. Additionally, these materials exhibit improved endothelialisation compared to those functionalised with only integrin-binding ligands, potentiating their use in blood contacting biomedical device applications. As integrins and syndecan-4 are ubiquitously expressed by the adherent cells in the human body, this new class of biomaterials will likely find use in a much wider range of applications, such as tissue engineering scaffolds where mechanotransduction is required for the maturation of neotissues in bioreactors.

\section{Acknowledgements}

The authors would like to thank the Research Training Program (RTP), the Endeavor IPRS, and the Australian Postgraduate Awards (APA) for providing financial support to this project. We would also like to thank the Particulate Fluids Processing Centre (PFPC) and the Materials Characterisation and Fabrication Platform (MCFP).

\section{Conflict of Interest}

The authors declare no conflict of interest 


\section{References}

[1] Geiger B, Bershadsky A, Pankov R, Yamada KM. Transmembrane crosstalk between the extracellular matrix and the cytoskeleton. Nat Rev Mol Cell Biol 2001;2:793-805. doi:10.1038/35099066.

[2] Humphries JD, Byron A, Humphries MJ. Integrin ligands at a glance. J Cell Sci 2006;119:39013. doi:10.1242/jcs.03098.

[3] Karimi F, O’Connor AJ, Qiao GG, Heath DE. Integrin Clustering Matters: A Review of Biomaterials Functionalized with Multivalent Integrin-Binding Ligands to Improve Cell Adhesion, Migration, Differentiation, Angiogenesis, and Biomedical Device Integration. Adv Healthc Mater 2018. doi:10.1002/adhm.201701324.

[4] Massia SP, Hubbell JA. An RGD spacing of $440 \mathrm{~nm}$ is sufficient for integrin $\alpha \mathrm{v} \beta 3$-mediated fibroblast spreading and $140 \mathrm{~nm}$ for focal contact and stress fiber formation. J Cell Biol 1991;114:1089. doi:10.1083/jcb.114.5.1089.

[5] Hersel U, Dahmen C, Kessler H. RGD modified polymers: Biomaterials for stimulated cell adhesion and beyond. Biomaterials 2003;24:4385-415. doi:10.1016/S0142-9612(03)00343-0.

[6] Wang X, Heath DE, Cooper SL. Endothelial cell adhesion and proliferation to PEGylated polymers with covalently linked RGD peptides. J Biomed Mater Res A 2012;100:794-801. doi:10.1002/jbm.a.34026.

[7] Cherny RC, Honan MA, Thiagarajan P. Site-directed mutagenesis of the arginine-glycineaspartic acid in vitronectin abolishes cell adhesion. J Biol Chem 1993;268:9725-9.

[8] Noel S, Hachem A, Merhi Y, De Crescenzo G. Development of a polyester coating combining antithrombogenic and cell adhesive properties: Influence of sequence and surface density of adhesion peptides. Biomacromolecules 2015;16:1682-94. doi:10.1021/acs.biomac.5b00219.

[9] Larsen CC, Kligman F, Tang C, Kottke-Marchant K, Marchant RE. A biomimetic peptide fluorosurfactant polymer for endothelialization of ePTFE with limited platelet adhesion. Biomaterials 2007;28:3537-48. doi:10.1016/j.biomaterials.2007.04.026.

[10] Knight CG, Morton LF, Peachey AR, Tuckwell DS, Farndale RW, Barnes MJ. The collagenbinding a-domains of integrins $\alpha 1 / \beta 1$ and $\alpha 2 / \beta 1$ recognize the same specific amino acid sequence, GFOGER, in native (triple- helical) collagens. J Biol Chem 2000;275:35-40. doi:10.1074/jbc.275.1.35.

[11] Wojtowicz AM, Shekaran A, Oest ME, Dupont KM, Templeman KL, Hutmacher DW, et al. Coating of biomaterial scaffolds with the collagen-mimetic peptide GFOGER for bone defect repair. Biomaterials 2010;31:2574-82. doi:10.1016/j.biomaterials.2009.12.008.

[12] Bellis SL. Advantages of RGD peptides for directing cell association with biomaterials. Biomaterials 2011;32:4205-10. doi:10.1016/j.biomaterials.2011.02.029.

[13] Massia SP, Hubbell JA. Vascular endothelial cell adhesion and spreading promoted by the peptide REDV of the IIICS region of plasma fibronectin is mediated by integrin alpha 4 beta 1 . J Biol Chem 1992;267:14019-26.

[14] Woods A, Couchman JR, Johansson S, Höök M. Adhesion and cytoskeletal organisation of fibroblasts in response to fibronectin fragments. EMBO J 1986;5:665. doi:10.1002/j.14602075.1986.tb04265.x.

[15] Bloom L, Ingham KC, Hynes RO. Fibronectin regulates assembly of actin filaments and focal contacts in cultured cells via the heparin-binding site in repeat III13. Mol Biol Cell 1999;10:1521-36. doi:10.1091/mbc.10.5.1521.

[16] Saoncella S, Echtermeyer F, Denhez F, Nowlen JK, Mosher DF, Robinson SD, et al. Syndecan4 signals cooperatively with integrins in a Rho-dependent manner in the assembly of focal adhesions and actin stress fibers. Proc Natl Acad Sci U S A 1999;96:2805-10. 
doi:10.1073/pnas.96.6.2805.

[17] Woods A, Longley RL, Tumova S, Couchman JR. Syndecan-4 binding to the high affinity heparin-binding domain of fibronectin drives focal adhesion formation in fibroblasts. Arch Biochem Biophys 2000;374:66-72. doi:10.1006/abbi.1999.1607.

[18] Kim CW, Goldberger OA, Gallo RL, Bernfield M. Members of the syndecan family of heparan sulfate proteoglycans are expressed in distinct cell-, tissue-, and development-specific patterns. Mol Biol Cell 1994;5:797-805. doi:10.1091/mbc.5.7.797.

[19] Woods A. Syndecans: Transmembrane modulators of adhesion and matrix assembly. J Clin Invest 2001;107:935-41. doi:10.1172/JCI12802.

[20] Sarrazin S, Lamanna WC, Esko JD. Heparan sulfate proteoglycans. Cold Spring Harb Perspect Biol 2011;3:a004952. doi:10.1101/cshperspect.a004952.

[21] Tkachenko E, Rhodes JM, Simons M. Syndecans: New kids on the signaling block. Circ Res 2005;96:488-500. doi:10.1161/01.RES.0000159708.71142.c8.

[22] Woods A, McCarthy JB, Furcht LT, Couchman JR. A synthetic peptide from the COOHterminal heparin-binding domain of fibronectin promotes focal adhesion formation. Mol Biol Cell 1993;4:605-13. doi:10.1091/mbc.4.6.605.

[23] LeBaron RG, Esko JD, Woods A, Johansson S, Hook M. Adhesion of glycosaminoglycandeficient Chinese hamster ovary cell mutants to fibronectin substrata. J Cell Biol 1988;106:94552. doi:10.1083/jcb.106.3.945.

[24] Huhtala P, Humphries MJ, McCarthy JB, Tremble PM, Werb Z, Damsky CH. Cooperative signaling by $\alpha 5 \beta 1$ and $\alpha 4 \beta 1$ integrins regulates metalloproteinase gene expression in fibroblasts adhering to fibronectin. J Cell Biol 1995;129:867-79. doi:10.1083/jcb.129.3.867.

[25] Longley RL, Woods A, Fleetwood A, Cowling GJ, Gallagher JT, Couchman JR. Control of morphology, cytoskeleton and migration by syndecan-4. J Cell Sci 1999;112:3421-31.

[26] Karimi F, Thombare VJ, Hutton CA, O’Connor AJ, Qiao GG, Heath DE. Beyond RGD; nanoclusters of syndecan- and integrin-binding ligands synergistically enhance cell/material interactions. Biomaterials 2018;187:81-92. doi:10.1016/J.BIOMATERIALS.2018.10.002.

[27] Karimi F, McKenzie TG, O’Connor AJ, Qiao GG, Heath DE. Nano-scale clustering of integrinbinding ligands regulates endothelial cell adhesion, migration, and endothelialization rate: Novel materials for small diameter vascular graft applications. J Mater Chem B 2017. doi:10.1039/c7tb01298e.

[28] Baeyens N, Mulligan-Kehoe MJ, Corti F, Simon DD, Ross TD, Rhodes JM, et al. Syndecan 4 is required for endothelial alignment in flow and atheroprotective signaling. Proc Natl Acad Sci U S A 2014;111:17308-13. doi:10.1073/pnas.1413725111.

[29] Bellin RM, Kubicek JD, Frigault MJ, Kamien AJ, Steward RL, Barnes HM, et al. Defining the role of syndecan-4 in mechanotransduction using surfacemodification approaches. Proc Natl Acad Sci U S A 2009;106:22102-7. doi:10.1073/pnas.0902639106.

[30] Elfenbein A, Simons M. Syndecan-4 signaling at a glance. J Cell Sci 2013;126:3799-804. doi:10.1242/jcs.124636.

[31] Melchiorri AJ, Hibino N, Fisher JP. Strategies and techniques to enhance the in situ endothelialization of small-diameter biodegradable polymeric vascular grafts. Tissue Eng - Part B Rev 2013;19:292-307. doi:10.1089/ten.teb.2012.0577.

[32] Pang JH, Farhatnia Y, Godarzi F, Tan A, Rajadas J, Cousins BG, et al. In situ Endothelialization: Bioengineering Considerations to Translation. Small 2015;11:6248-64. doi:10.1002/smll.201402579.

[33] Wang X, Cooper S. Adhesion of endothelial cells and endothelial progenitor cells on peptidelinked polymers in shear flow. Tissue Eng Part A 2013;19:1113-21. doi:10.1089/ten.TEA.2011.0653. 
[34] Li YSJ, Haga JH, Chien S. Molecular basis of the effects of shear stress on vascular endothelial cells. J Biomech 2005;38:1949-71. doi:10.1016/j.jbiomech.2004.09.030.

[35] Traub O, Berk BC. Laminar shear stress: Mechanisms by which endothelial cells transduce an atheroprotective force. Arterioscler Thromb Vasc Biol 1998;18:677-85. doi:10.1161/01.ATV.18.5.677.

[36] Pahakis MY, Kosky JR, Dull RO, Tarbell JM. The role of endothelial glycocalyx components in mechanotransduction of fluid shear stress. Biochem Biophys Res Commun 2007;355:22833. doi:10.1016/j.bbrc.2007.01.137.

[37] Shyy JYJ, Chien S. Role of integrins in endothelial mechanosensing of shear stress. Circ Res 2002;91:769-75. doi:10.1161/01.RES.0000038487.19924.18.

[38] Woods A, Couchman JR. Syndecan-4 and focal adhesion function. Curr Opin Cell Biol 2001;13:578-83. doi:10.1016/S0955-0674(00)00254-4.

[39] Simons M, Horowitz A. Syndecan-4-mediated signalling. Cell Signal 2001;13:855-62. doi:10.1016/S0898-6568(01)00190-5.

[40] Usami S, Chen HH, Zhao Y, Chien S, Skalak R. Design and construction of a linear shear stress flow chamber. Ann Biomed Eng 1993;21:1113-21. doi:10.1007/BF02368167.

[41] Plouffe BD, Njoka DN, Harris J, Liao J, Horick NK, Radisic M, et al. Peptide-mediated selective adhesion of smooth muscle and endothelial cells in microfluidic shear flow. Langmuir 2007;23:5050-5. doi:10.1021/la0700220.

[42] Shao G, Wu J, Cai Z, Wang W. Fabrication of elastomeric high-aspect-ratio microstructures using polydimethylsiloxane (PDMS) double casting technique. Sensors Actuators, A Phys 2012;178:230-6. doi:10.1016/j.sna.2012.01.034.

[43] Di H, Martin GJO, Dunstan DE. A microfluidic system for studying particle deposition during ultrafiltration. J Memb Sci 2017;532:68-75. doi:10.1016/j.memsci.2017.03.017.

[44] Tegoulia VA, Cooper SL. Leukocyte adhesion on model surfaces under flow: Effects of surface chemistry, protein adsorption, and shear rate. J Biomed Mater Res 2000;50:291-301. doi:10.1002/(SICI)1097-4636(20000605)50:3<291::AID-JBM2>3.0.CO;2-1.

[45] Pfaff M, Tangemann K, Müller B, Gurrath M, Müller G, Kessler H, et al. Selective recognition of cyclic RGD peptides of NMR defined conformation by alpha IIb beta 3, alpha V beta 3, and alpha 5 beta 1 integrins. J Biol Chem 1994;269:20233-8.

[46] Masters KS, Anseth KS. Cell-Material Interactions 2004;29:7-46. doi:10.1016/S00652377(03)29002-5.

[47] Heath DE. Promoting Endothelialization of Polymeric Cardiovascular Biomaterials. Macromol Chem Phys 2017;218. doi:10.1002/macp.201600574.

[48] Heath DE, Cooper SL. The development of polymeric biomaterials inspired by the extracellular matrix. J Biomater Sci Polym Ed 2017;28:1051-69. doi:10.1080/09205063.2017.1297285.

[49] Suzuki N, Ichikawa N, Kasai S, Yamada M, Nishi N, Morioka H, et al. Syndecan Binding Sites in the Laminin $\alpha 1$ Chain G Domain. Biochemistry 2003;42:12625-33. doi:10.1021/bi030014s.

[50] Nomizu M, Woo Ho Kim, Yamamura K, Utani A, Song SY, Otaka A, et al. Identification of cell binding sites in the laminin $\alpha 1$ chain carboxyl- terminal globular domain by systematic screening of synthetic peptides. J Biol Chem 1995;270:20583-90. doi:10.1074/jbc.270.35.20583.

[51] Hoffman MP, Nomizu M, Roque E, Lee S, Jung DW, Yamada Y, et al. Laminin-1 and laminin2 G-domain synthetic peptides bind syndecan-1 and are involved in acinar formation of a human submandibular gland cell line. J Biol Chem 1998;274:28633-41. doi:10.1074/jbc.273.44.28633.

[52] Hozumi K, Suzuki N, Nielsen PK, Nomizu M, Yamada Y. Laminin $\alpha 1$ chain LG4 module promotes cell attachment through syndecans and cell spreading through integrin $\alpha 2 \beta 1$. J Biol Chem 2006;281:32929-40. doi:10.1074/jbc.M605708200. 
[53] Murthy SK, Sin A, Tompkins RG, Toner M. Effect of flow and surface conditions on human lymphocyte isolation using microfluidic chambers. Langmuir 2004;20:11649-55. doi:10.1021/la048047b.

[54] Papaioannou TG, Stefanadis C. Vascular wall shear stress: Basic principles and methods. Hell J Cardiol 2005;46:9-15.

[55] Sakariassen KS, Orning L, Turitto VT. The impact of blood shear rate on arterial thrombus formation. Futur Sci OA 2015;1:FSO30. doi:10.4155/fso.15.28.

[56] Resnick N, Yahav H, Shay-Salit A, Shushy M, Schubert S, Zilberman LCM, et al. Fluid shear stress and the vascular endothelium: For better and for worse. Prog Biophys Mol Biol 2003;81:177-99. doi:10.1016/S0079-6107(02)00052-4.

[57] Young EWK, Simmons CA. Macro- and microscale fluid flow systems for endothelial cell biology. Lab Chip 2010;10:143-60. doi:10.1039/b913390a.

[58] Savage B, Almus-Jacobs F, Ruggeri ZM. Specific synergy of multiple substrate-receptor interactions in platelet thrombus formation under flow. Cell 1998;94:657-66. doi:10.1016/S0092-8674(00)81607-4.

[59] Boulbitch A, Guttenberg Z, Sackmann E. Kinetics of membrane adhesion mediated by ligandreceptor interaction studied with a biomimetic system. Biophys J 2001;81:2743-51. doi:10.1016/S0006-3495(01)75917-6.

[60] Khalili AA, Ahmad MR. A Review of cell adhesion studies for biomedical and biological applications. Int J Mol Sci 2015;16:18419-18184. doi:10.3390/ijms160818149.

[61] Choi Y, Chung H, Jung H, Couchman JR, Oh ES. Syndecans as cell surface receptors: Unique structure equates with functional diversity. Matrix Biol 2011;30:93-9. doi:10.1016/j.matbio.2010.10.006.

[62] Lee MH, Ducheyne P, Lynch L, Boettiger D, Composto RJ. Effect of biomaterial surface properties on fibronectin- $\alpha 5 \beta 1$ integrin interaction and cellular attachment. Biomaterials 2006;27:1907-16. doi:10.1016/j.biomaterials.2005.11.003.

[63] Hu B, Finsinger D, Peter K, Guttenberg Z, Barmann M, Kessler H, et al. Intervesicle crosslinking with integrin $\alpha(\mathrm{IIb}) \beta 3$ and cyclic-RGD-lipopeptide. A model of cell-adhesion processes. Biochemistry 2000;39:12284-94. doi:10.1021/bi000144q.

[64] Parish CR. The role of heparan sulphate in inflammation. Nat Rev Immunol 2006;6:633. doi:10.1038/nri1918.

[65] Springer TA. Adhesion receptors of the immune system. Nature 1990;346:425. doi:10.1038/346425a0.

[66] McEver RP, Moore KL, Cummings RD. Leukocyte trafficking mediated by selectincarbohydrate interactions. J Biol Chem 1995;270:11025-8. doi:10.1074/jbc.270.19.11025.

[67] Lawrence MB, Springer TA. Leukocytes roll on a selectin at physiologic flow rates: Distinction from and prerequisite for adhesion through integrins. Cell 1991;65:859-73. doi:10.1016/00928674(91)90393-D.

[68] Y. Duan, S. Yu, P. Xu, X. Wang, X. Feng, Z. Mao, C. Gao, Co-immobilization of CD133 antibodies, vascular endothelial growth factors, and REDV peptide promotes capture, proliferation, and differentiation of endothelial progenitor cells, Acta biomaterialia 2019;96:137-148. doi: https://doi.org/10.1016/j.actbio.2019.07.004 


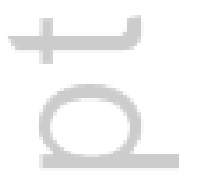

This article is protected by copyright. All rights reserved. 


\section{Figure Caption}

Figure 1. 2D geometry of flow chamber and wall shear stress profile at a flow rate of $400 \mu \mathrm{L} / \mathrm{min}$.

Figure 2. Schematic of Hele-Shaw laminar flow chamber fabrication.

Figure 3. (A) Chemical structure of MP and MPP-peptide polymers. (B) Generation of clustered surfaces by blending of non-functionalized polymer chains (MP, light blue) with highly peptide functionalized polymer chains (MPP-AG73/MPP-RGD, dark blue). The blending strategy creates nano-scale islands of high peptide density defined by the random coils of the functionalised polymer molecule

Figure 4. Quantification of HUVEC retention as a function of shear stress on various surfaces. Asterisks $\left({ }^{*}\right)$ represent statistical difference where ${ }^{* *} P<0.01 ;{ }^{*} P<0.05$. 
Figure 5. Representative confocal images of HUVECs stained for F-actin (red) and nucleus (blue) after exposure to shear stresses of 1,2 , or 3 dynes $/ \mathrm{cm}^{2}$ at $60 \times$ magnification. The cells were exposed to these shear stresses for $10 \mathrm{~h}$. Flow direction is from left to right. Scale bars represent $50 \mu \mathrm{m}$.

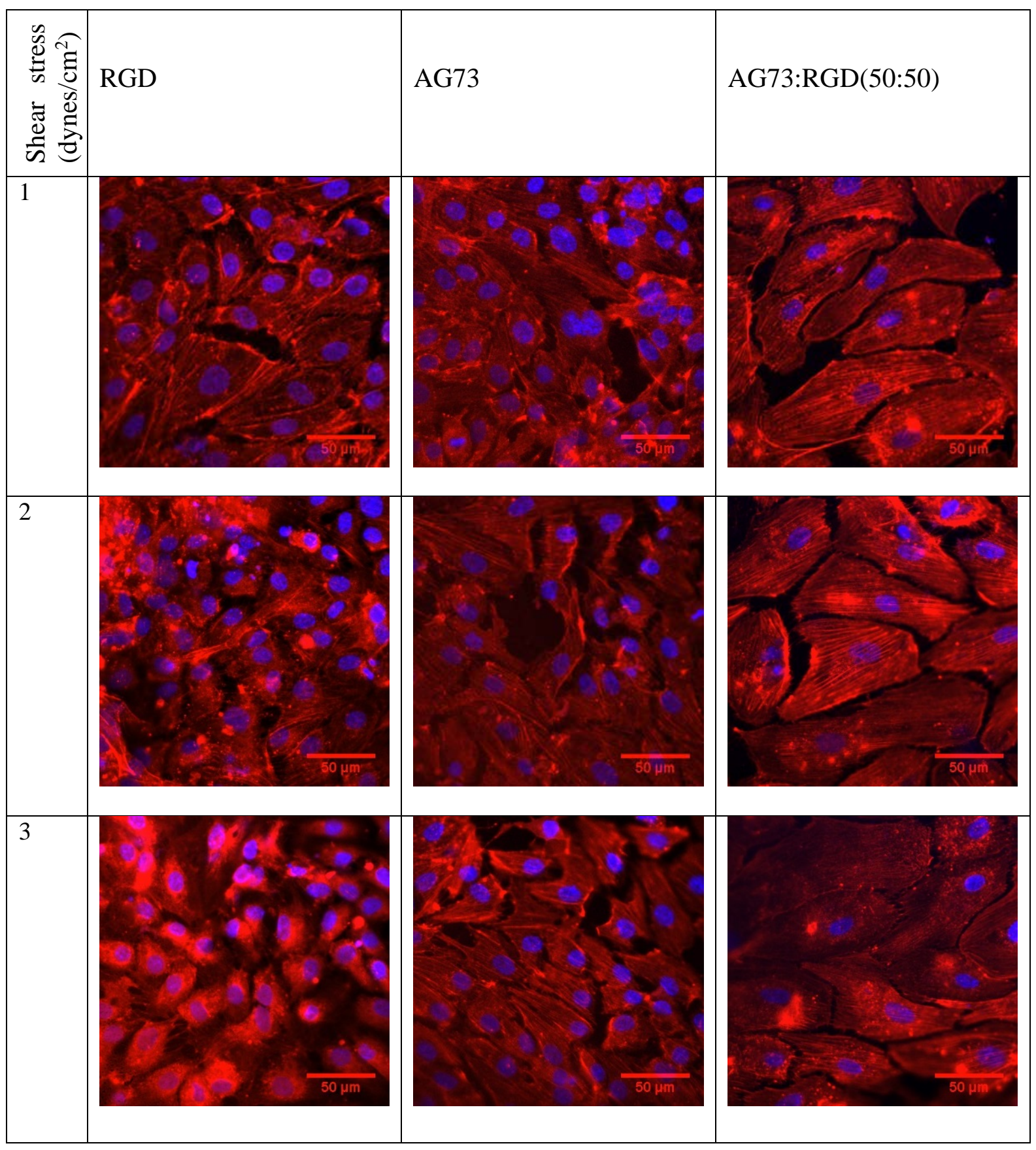


Figure 6. Quantification of HUVEC morphology and cytoskeletal development on various surfaces after exposure to shear stresses of 1,2 , or 3 dynes $/ \mathrm{cm}^{2}$ for $10 \mathrm{~h}$ : (A) projected cell area, (B) degree of alignment to the flow direction, (C) number of actin filaments per cell, (D) width of actin filaments, and (E) length of actin filaments $(\mathrm{n}>20)$. Asterisks $(*)$ represent statistical differences where $\alpha<0.01$. 
Figure 7. Representative images of HUVECs adhesion over 18 minutes on various surfaces at a shear stress of 0.6 dynes $/ \mathrm{cm}^{2}$ at $20 \times$ magnification. The cells were stained with AO (live, green) and PI (dead, red). Scale bars represent $100 \mu \mathrm{m}$.

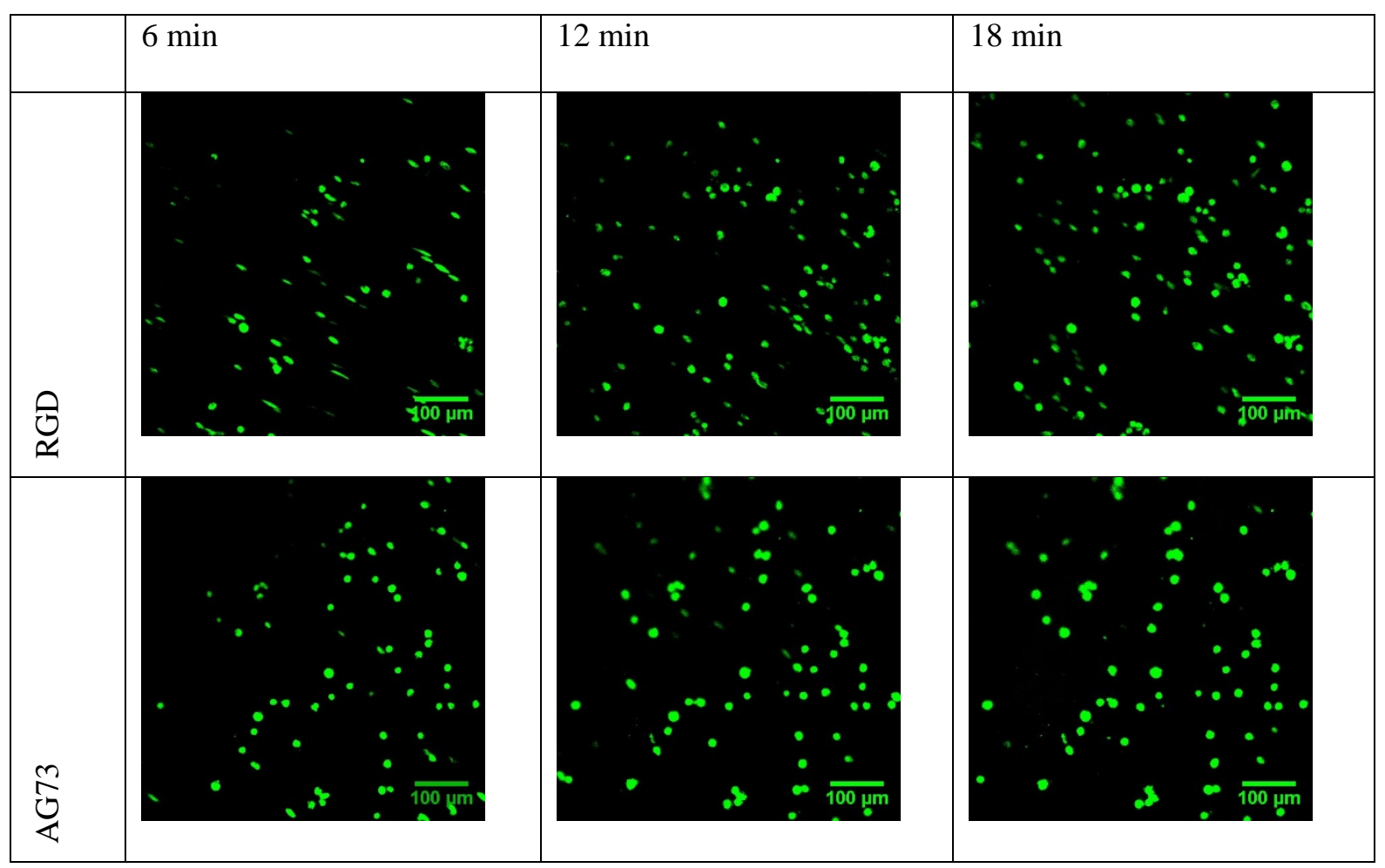




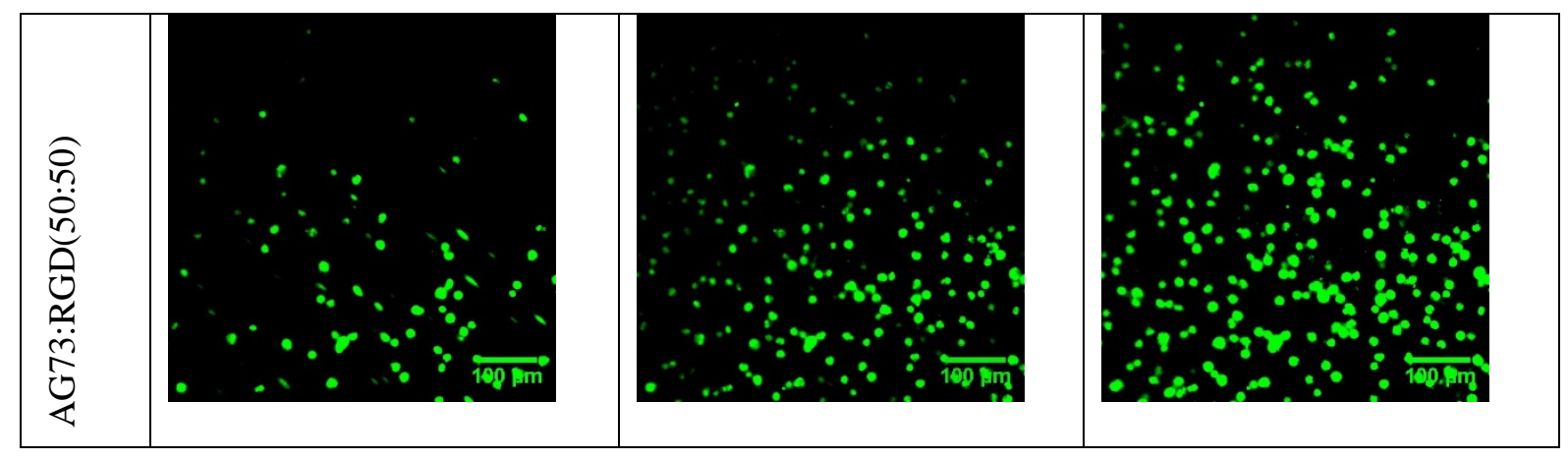

Figure 8. (A-C) Quantification of HUVEC adhesion as a function of time on various surfaces over a range of shear stresses (n=9). (D) Quantification of HUVEC adhesion after 18 minutes at 0.4 and 0.6 dynes $/ \mathrm{cm}^{2}$ on various surfaces. (E) Attachment rate constants of HUVECs on various surfaces as a function of shear stress. Asterisks $(*)$ represent statistical difference where $* * P<0.01 ;{ }^{*} P<0.05$ 


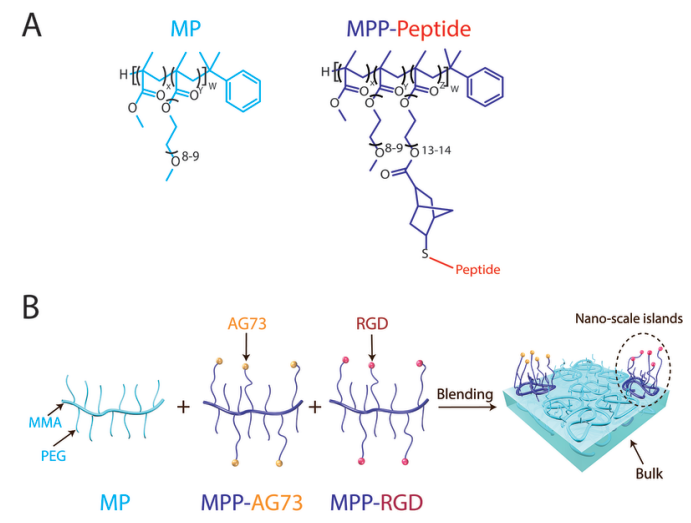

JBMA_37024_Figure3.tif

This article is protected by copyright. All rights reserved. 

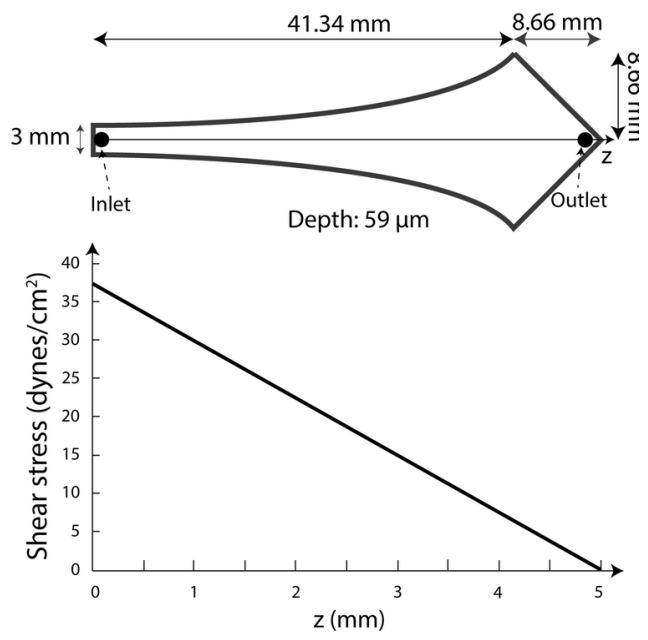

JBMA_37024_Figure 1.tif

This article is protected by copyright. All rights reserved. 


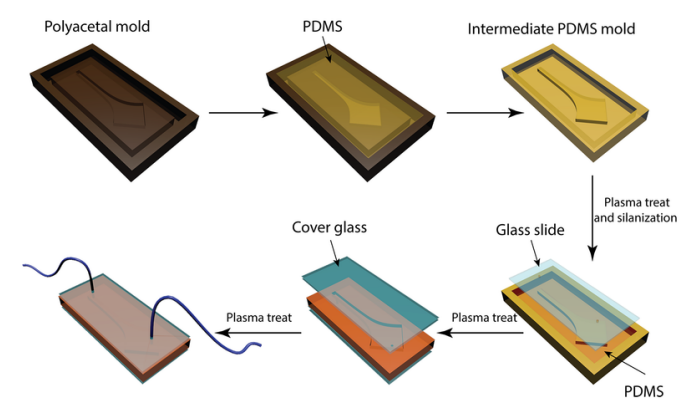

JBMA_37024_Figure 2.tif

This article is protected by copyright. All rights reserved. 


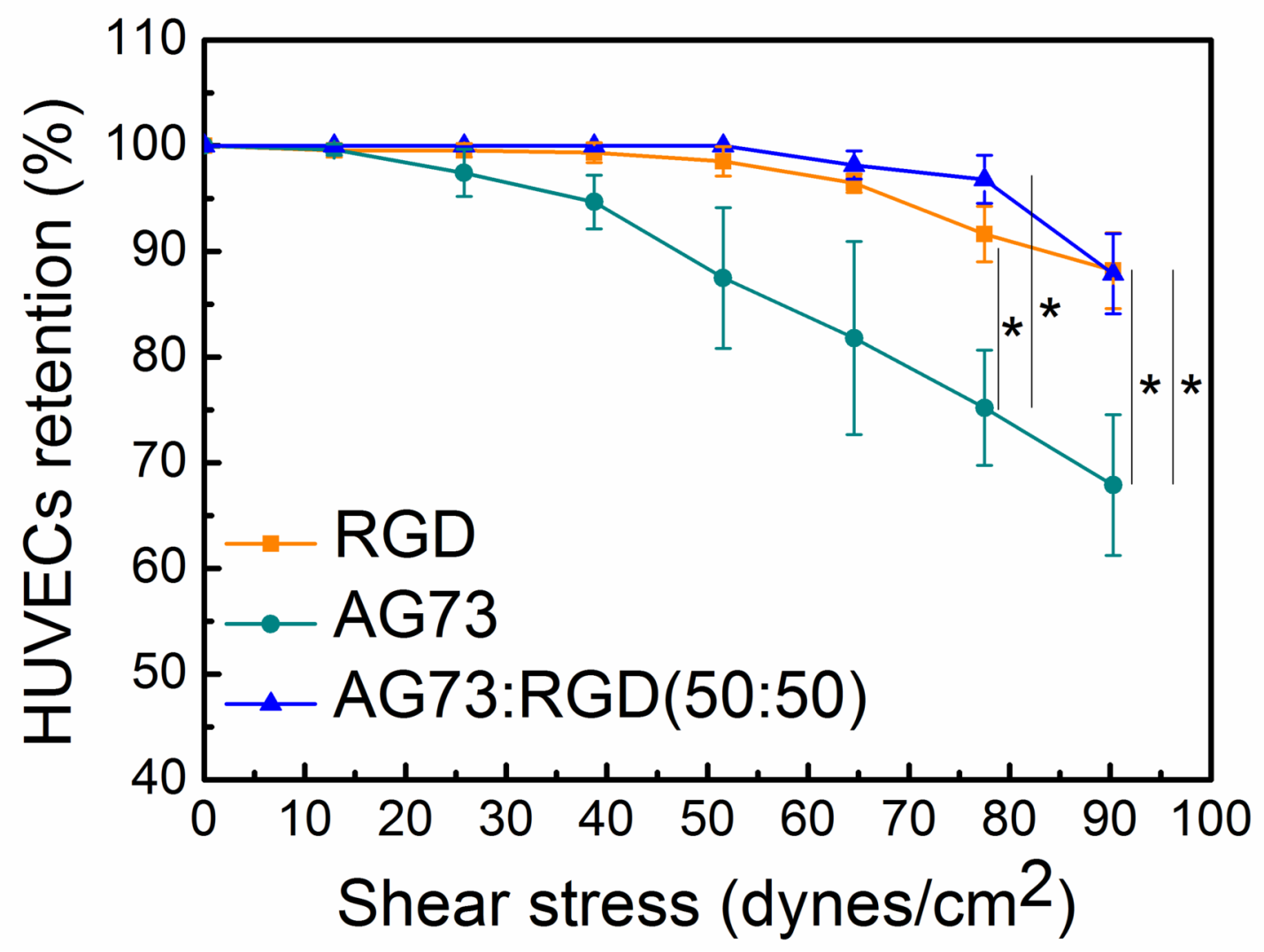

JBMA_37024_Figure 4.tif 

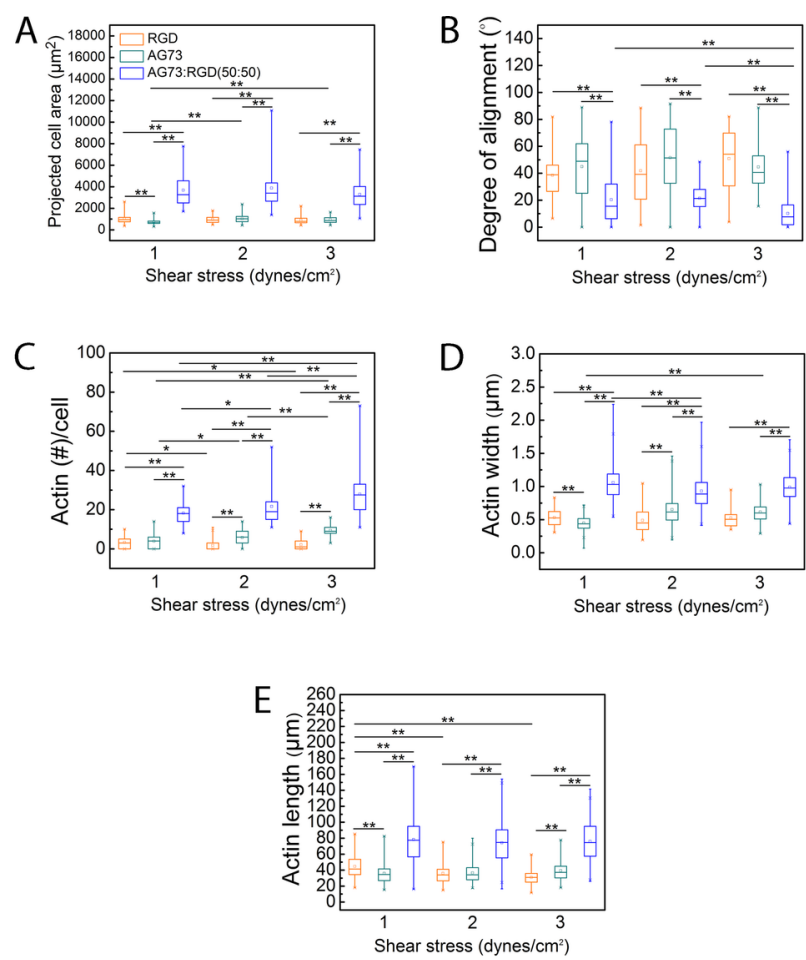

JBMA_37024_Figure 6-4.tif

This article is protected by copyright. All rights reserved. 

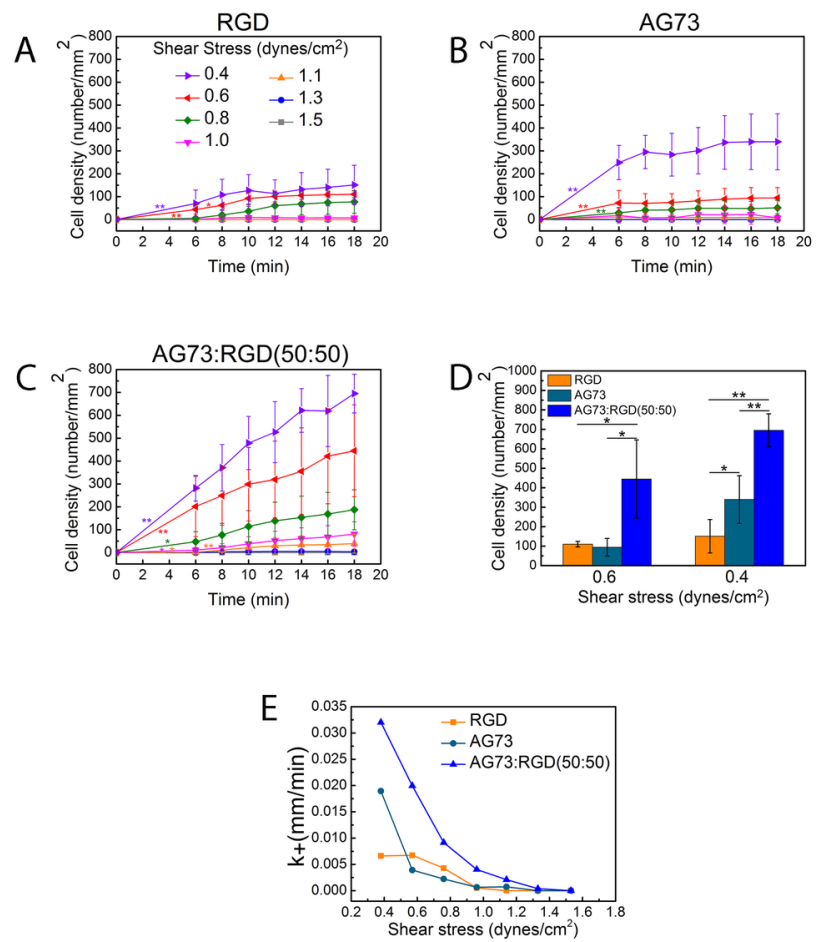

JBMA_37024_Figure 8-3.tif

This article is protected by copyright. All rights reserved. 


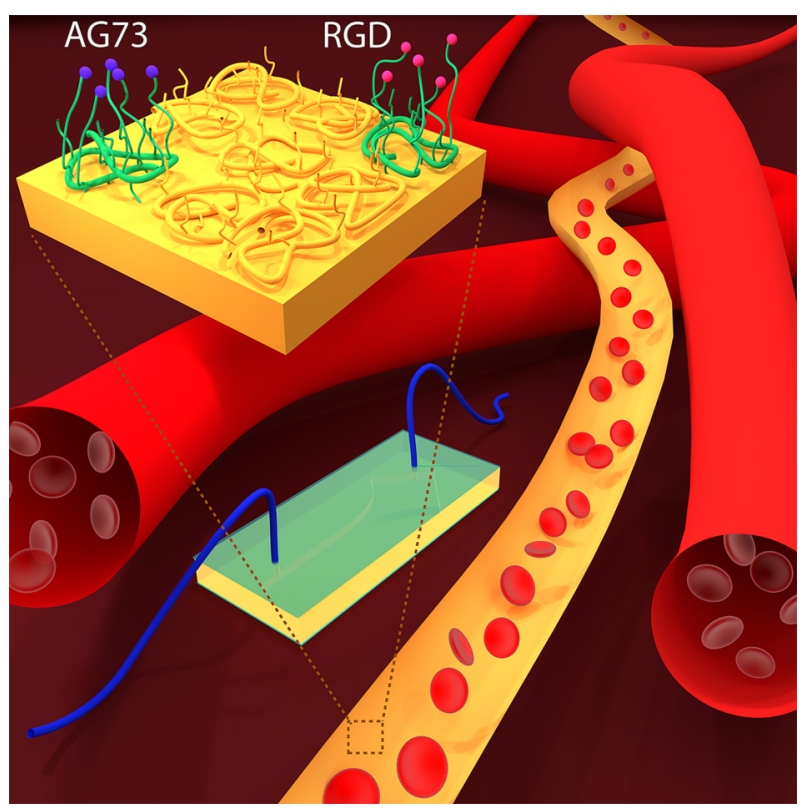

JBMA_37024_TOC-cover-600dp-2.tif

This article is protected by copyright. All rights reserved. 


\section{University Library}

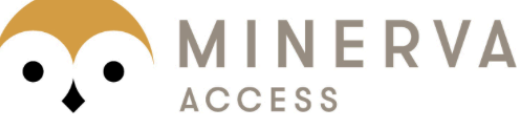

A gateway to Melbourne's research publications

Minerva Access is the Institutional Repository of The University of Melbourne

Author/s:

Karimi, F;Thombare, VJ;Hutton, CA;O'Connor, AJ;Qiao, GG;Heath, DE

Title:

Biomaterials functionalized with nanoclusters of integrin- and syndecan-binding ligands improve cell adhesion and mechanosensing under shear flow conditions

Date:

2020-06-29

\section{Citation:}

Karimi, F., Thombare, V. J., Hutton, C. A., O'Connor, A. J., Qiao, G. G. \& Heath, D. E. (2020). Biomaterials functionalized with nanoclusters of integrin- and syndecan-binding ligands improve cell adhesion and mechanosensing under shear flow conditions.

JOURNAL OF BIOMEDICAL MATERIALS RESEARCH PART A, 109 (3), pp.313-325. https:// doi.org/10.1002/jbm.a.37024.

Persistent Link:

http://hdl.handle.net/11343/275960 